\title{
Research on Influencing Factors and Promotion Strategies of College English Teachers' Efficacy
}

\author{
Ling Pan \\ College of Foreign Studies \\ Shandong Technology and Business University \\ Yantai, China 264005
}

\begin{abstract}
With the continuous development of English education, college English is also facing reform. English teachers are under increasing pressure. College English teachers of high quality play an important role in English education in colleges and universities, and improving their sense of efficacy has promoted the improvement of teachers' quality. The internal and external environment and the university situation affect teachers' sense of efficacy. The support of society and colleges, the self-improvement of teachers' psychology and ability, and the perfect evaluation system are needed in order to improve the teaching efficacy of college English teachers.
\end{abstract}

Keywords-college English teachers; efficacy; influencing factors; promotion strategies

\section{INTRODUCTION}

In recent years, higher education has developed rapidly as an important base for training talents. The teachers of colleges and universities shoulder the important mission of cultivating talents, inheriting civilization and serving the society. With the development of the economy and society, teachers of colleges and universities are constantly expanding, the quality is continuously improved and the structure is continuously optimized, which provides a strong guarantee for the training of talents. As an important basic course in college courses, English plays an important role in the teaching of colleges and universities. The sense of efficiency in college English teaching is of great significance to improve students' achievements and achieve good teaching results. Teaching efficacy is a factor to explain teachers' teaching motivation, and it is also an important condition that affects teachers' teaching enthusiasm and teaching quality. Teachers' effectiveness is affected by many factors, among which the environmental factors occupy a very important position. Therefore, the analysis of the environmental factors of the teaching efficacy of College English teachers is of great significance. In addition, in universities, the lack of attention to the teaching of English has a negative impact on the sense of teaching efficacy. This situation needs to be solved. This article will also discuss the relevant solutions from the aspect of the sense of teaching efficacy. It is particularly important for college English teachers to improve their teaching quality and enhance their sense of teaching efficacy.

\section{ThE THEORETICAL SOURCE OF TEACHERS' SENSE OF EFFICACY}

The study of teacher efficacy comes from two assessment reports from Rand Co-education. Two evaluation reports from Armor in 1976 and Berman in 1977 respectively pointed out the importance of teachers' sense of efficacy, that is, teachers' sense of self-efficacy is an important variable factor that affects students' performance, and is also the key to the success of educational innovation.

Bandura, an American Psychologist, believes that selfefficacy refers to individuals' perception and belief in their ability to effectively control their various aspects of life, and is a kind of judgement of future state. It shows whether an individual can practice a kind of expectation in a specific situation to achieve some purpose. Later researchers put forward a more perfect framework and theoretical model around Bandura's theory, so that they can better study teachers' expectations and judgments about their teaching ability. Expectations are divided into two parts: outcome expectation and effectiveness expectation. The result is expected to be the individual's presumption of the possibility of the result of his behavior, and the expectation of efficiency is the subjective judgment of an individual's ability to act.

Teachers' sense of teaching efficacy refers to the perception and belief that teachers can effectively fulfill their teaching work and achieve teaching goals in teaching activities. It is a kind of perception and belief that teachers believe that they can promote students' learning through hard work and bring positive and effective influence to their students. The research on the sense of teacher efficacy at home and abroad shows that the sense of efficacy affects the initiative and enthusiasm of teachers in the teaching activities, the attention and input to the teaching work, the interaction with the students and the insistence of overcoming difficulties to accomplish the goal.

\section{STUdY OF THE SENSE OF EFFICACY OF COLLEGE ENGLISH TEACHERS}

Teachers' sense of teaching efficacy consists of two dimensions: general teaching efficacy and personal teaching efficacy. The general sense of teaching efficacy refers to the opinions and judgments of teachers on the relationship 
between teaching and learning. The sense of personal teaching efficacy refers to the perception and belief that the teacher is able to accomplish the task of teaching and to teach the ability of the students.

According to the statistics and research results of Zhou Jingjing (2006) and Wang Shiruo (2009) respectively on the teaching efficacy of College English teachers in the master's thesis, most teachers are in the middle and above level (respectively $84 \%, 92 \%, 88 \%, 84 \%$ ) in the four dimensions of classroom management, teaching material presentation, teaching strategy and teacher-student interaction. The research shows that the overall sense of teaching efficacy of Chinese College English teachers is good, and the overall level is above medium and above level (84\% of the surveyed teachers). In addition, Yu Jiajie's investigation report on English teachers of Higher Vocational and technical colleges (2010) shows that higher vocational college English teachers have a high sense of teaching efficacy, in which the general sense of teaching efficacy is lower than personal teaching efficacy ( 3 points: 4 points), which is worthy of satisfaction.

\section{INFLUENCING FACTORS}

The sense of effectiveness of College English teachers is not natural and spontaneous. Its formation needs a specific teaching environment and a certain period of time. The existing research shows that the external conditions of society and colleges and the internal conditions of teachers' self-have a significant impact on Teachers' sense of teaching efficacy. And English as a basic course is influenced more greatly.

\section{A. External Factors}

1) The influence of social environment: Sufficient support from the society makes it possible for individuals to minimize these negative effects on physical and mental conditions in the face of various pressures and difficulties, in order to ease the sense of stress and to maintain and improve the physical and mental health of the individual.

Various aspects such as the respect for teachers' profession, the recognition of teachers, the economic treatment of teachers, and the rights given to teachers affect the development of teachers, and have a great influence on the sense of teachers' efficacy. For example, after improving the treatment of teachers in primary and secondary schools, the sense of efficacy of primary and secondary school teachers has been improved to different extent. In addition, the degree of respect for teachers is far less than the former, the expectations of the parents are getting higher and higher, and the teachers bear more and more responsibility. At the same time, the more complaints are borne, which makes many teachers lose their sense of superiority. In various colleges and universities, English majors have been forced to become a relatively cold major from the fashionable and hot majors in the past, and the pressure of English Majors in Colleges and universities is increasing.

2) The influence of college environment: Colleges are the environment for teachers to work, and the atmosphere of colleges affects teachers' work attitudes and behaviors. According to the results of Xin Tao's study in 1994, the three factors that have a significant impact on Teachers' sense of personal teaching are: the relationship between teachers and students, the development conditions of the school style and the education work. And the teachers' general sense of teaching efficacy is significantly influenced by the support system and the development conditions provided by the educational work. Ashton (1984) will affect teachers' self-efficacy factors in terms of school atmosphere, teacher morale, principal's leadership style and school hardware. Woolfolk\&Hoy (1990) thinks that the high achievement goals of other teachers and the healthy ethos of schools can influence individual teachers and improve their personal teaching efficacy. Dembo \& Gibson (1995) considers that the key factor affecting teachers' efficacy is the size of classes. The report indicates that teachers' teaching efficacy is inversely proportional to the number of classes, that is, the greater the number, the lower the teaching effect and teaching efficacy. Most college teachers are teachers who teach non - English majors. The class is basically a large class, with a large number of students, forty or fifty at least, and seventy or eighty at most. In such an environment, teaching efficacy will be reduced to some extent.

3) The influence of family environment: Family is everyone's energy supplement station, and teachers are no exception. The support of the family is conducive to the better development of the teachers, so that they can devote themselves to the teaching work, improve their enthusiasm for work and have a high sense of teaching efficacy.

4) The influence of college situation: Since 2003, China has carried out the teaching evaluation of universities nationwide. Although the educational and academic circles have commended and disputed about this, the evaluation work has aroused the importance of teachers' work in various colleges and universities, and improved teachers' teaching level. In the preparation for the assessment, teachers are giving full preparation and learning from each other, giving feedback and monitoring progress. The mutual support and help between these teachers greatly improve the teaching level of teachers, and the improvement of teaching quality is undoubtedly the affirmation of teachers' success, thus promoting the improvement of teachers' sense of teaching efficacy.

\section{B. Internal Factors}

Internal factors refer to teachers' personal factors, which mainly refer to the influence of academic qualifications, teaching age, teaching ability and other factors on Teachers' teaching efficacy.

1) Teacher's personal ability and teaching experience: Each teacher has different abilities and different teaching efficacy. Teachers with strong abilities are usually more effective than those with less ability. The successful 
experience of teachers' personal growth and development is of positive significance to the improvement of teachers' sense of teaching efficacy. Teachers with higher academic qualifications believe that their abilities are better than other teachers, and think that they have the conditions and strength to overcome hardships and get out of the lows. Teachers with longer teaching age, teachers who have won teaching awards or teachers who are well received by students are also more confident in their abilities. These teachers have accumulated rich professional knowledge, psychological knowledge as well as corresponding teaching skills and communication skills. The effect of teaching is increasing, and the sense of teaching efficiency is becoming stronger and stronger. The personal experience of university teachers is the most important information source for the formation and development of college teachers' sense of teaching efficacy. Especially for English teachers, it is more challenging to their own control and organizational strength than those in a small class. Teachers who are highly educated or experienced in teaching are naturally more competent.

2) Teacher's alternative experience: Alternative experience is also an important factor affecting the teaching efficacy of College English teachers. Alternative experience refers to the understanding of the expected ability of one's own behavior and results by observing the behavior of others, paying attention to the information of the course of action of others, forming expectations of their own behavior and results. In general, teachers in Colleges and universities should strengthen their personal ability, improve the teaching effect, not only accumulate their own experience, but also read materials or observe the successful experience of others. Observing the vicarious experience of imitation and symbolic imitation has a lasting effect on the judgement of individual self-efficacy. College English teachers, especially new teachers, learn from the experience of old teachers by listening to their lessons, so as to make themselves successful and improve their sense of teaching efficacy.

There are still other factors that have an important influence on teachers' sense of teaching efficacy, including the influence of school atmosphere, interpersonal relationship, material environment and working conditions. School atmosphere is mainly the academic atmosphere of the school and the conduct of scientific research. It also includes the unity and cooperation between teachers and good exchange of experience. English learning needs a good atmosphere of learning and good study style. Interpersonal relationship also has a certain influence on Teachers' sense of teaching efficacy, mainly refers to the relationship between teachers and students, students are willing to take English classes, and actively speak in the classroom and communicate with teachers, including the relationship between teachers and teachers, the unity and cooperation between teachers, active communication and learning. The material environment refers to the teaching facilities of the school. As a language subject, English is different from the traditional teaching. It needs more advanced teaching equipment, such as voice room, multimedia classroom and so on. Therefore, the material conditions are relatively good, so the teacher's sense of teaching efficacy will be improved accordingly. The conditions of work development will also have a certain impact on the sense of efficacy. If teachers can see the conditions and future of development, the teaching quality and teaching level will be promoted more actively in teaching, and they will be more confident in themselves. Then the sense of teaching efficiency will be higher and the teaching work will be more favorable.

\section{The Role of SENSE OF EFFICACY IN COLLEGE ENGLISH TEACHING SYSTEM}

The sense of efficacy of college English teachers plays a very important role in the whole teaching system, but these functions are often not directly reflected in a specific teaching index, but indirectly affect the various elements of the teaching, and ultimately play a role in English teaching. Because of this, teachers' sense of efficacy has not received enough attention for a long time.

As to the role of sense of efficacy in the English teaching system in colleges and universities, the academic community has basically identified it as an "intermediary role" at present. In a comprehensive way, this intermediary role is reflected in the influence of the following factors.

\section{A. Influencing Teachers' Teaching Behavior}

In English teaching, teachers need feedback information, such as learning enthusiasm, classroom atmosphere, examination results, and so on. If feedback information is negative, teachers will improve or cancel the original teaching behavior. If feedback information is positive, teachers will significantly encourage the original teaching activities. The teaching behavior is constantly perfected. Teachers with high efficiency will actively explore and summarize the problems when they encounter problems, while teachers with low efficiency will consider their shortcomings, and become frustrated, and then the teaching will be forced to the passive position.

\section{B. Influencing the Teaching Result}

The sense of efficacy has a significant incentive and encouragement effect on Teachers' teaching behavior. When teachers feel their own teaching receive others' recognition or when the actual teaching effect is produced, teachers' enthusiasm will be more invested in the teaching activities. The attempt to new teaching methods, the sense of responsibility to students as well as the motivation to update their own teaching knowledge become more powerful. On the influence of teacher efficacy on teaching effect, in a study of Chinese scholar Xin Tao in 2001, it was found that college English teachers with a high sense of efficacy show higher students' passing rate of CET-4 and CET-6, higher students' learning enthusiasm and better evaluation on teachers. 


\section{Influencing the Cooperation Between Teachers and Students}

Generally speaking, the teaching level and state of the teacher will affect the students' learning effect, but in turn, the students' learning situation will also have a symmetrical influence on the sense of effectiveness of the teachers. The teacher's foreign language teaching activities will also be influenced by the language teaching environment, teaching design, teaching method and other factors. The intermediary variable is the teacher's sense of efficacy.

\section{Influencing Teachers' Personality Traits}

Teachers' personality traits are shown as teaching emotions in teaching. According to modern psychology theory, foreign language teaching is of high intensity and rapid change. The work pressure can easily make teachers feel tired and slack, and then have adverse effects on the whole teaching. The sense of efficacy can adjust the teachers' disadvantage in teaching pressure. Rationale gives teachers more willpower and full of emotions. If teachers have a low sense of efficacy, they tend to attribute it to their poor ability in the face of problems such as heavy teaching tasks, students' incooperation, and poor teaching effect, which will cause depression and aggravate negative psychological factors. If teachers have a high sense of efficacy, they can actively adjust their psychological state, and seek ways to encourage self - expression through self - suggestion, and then adjust their mental state.

\section{PROMOTION STRATEGIES}

\section{A. Effective External Support}

1) Support from the society: The whole society should strive to create an atmosphere of respecting teachers, create a harmonious environment, lighten the psychological burden of teachers, and make them happy and active. Our country has always attached great importance to English education, and now it has set up English lessons from primary schools, but the degree of attention to college English teachers is obviously less than that of teachers in primary schools. Therefore, it is very important to improve the status of college teachers, especially college English teachers.

2) Support from colleges: Teachers carry out teaching activities in colleges, and the environment of colleges directly affects teachers' emotions. colleges should create a comfortable, fair and open environment for teachers. Colleges should encourage teachers to actively participate in college administration, attach importance to teachers' opinions, and give teachers certain decision-making power. A student \& teacher-- centered college which focuses on teaching is bound to enhance teachers' sense of belonging and enhance teachers' sense of efficacy.

\section{B. Continuous Internal Improvement}

1) Proper training and further study: We should carry out theoretical study and practical guidance for new teachers. The tutorial system has always been attached importance to in colleges and universities. New teachers always lack the teaching experience and the skill, and expert teachers can help the new ones to analyze the teaching task, provide teaching experience and methods, and give psychological support, in order to promote the development of those new teachers.

Colleges should actively encourage in-service teachers to participate in various aspects of training and further education. Proper training and further training have a positive effect on teachers' teaching and scientific research. Learning successful teaching cases, mastering various teaching methods and improving teaching skills will enhance teachers' sense of teaching efficacy. Besides learning scientific research frontiers and obtaining scientific research achievements will also better promote the development of teachers.

2) Attention to psychological health: Psychological health is one of the key elements of teachers' comprehensive quality. Healthy mental state is a prerequisite for the improvement and development of teachers. First of all, teachers should have a clear goal and put a positive attitude into work and life. In the face of difficulties, they do not lose their fighting spirit, and their emotions are not easily fluctuated in case of negative effects. Secondly, we should learn psychological hints. Through physical training, travel and other ways to regulate emotions, try to find effective ways to relieve the pressure in time.

College English teachers are facing great challenges. Although the importance of English is understood, college English education has always been a topic of debate, and it has been extended to the discussion whether college English should be regarded as a required course. This is a severe challenge for college teachers. Teachers at such a time of crisis will inevitably reduce their sense of efficacy. Teachers should improve their psychological endurance, not only to teach the current stage of teaching, but also to expand their knowledge scope to cope with English reform.

3) Complete evaluation feedback: Reasonable and appropriate evaluation index and evaluation methods are conducive to the increase of teachers' sense of efficacy. From the reality of each college teachers, a fair and just judgement and fair evaluation of teachers will make teachers get more objective feedback, and help teachers to sum up their experiences and lessons from the actual situation, and then teachers correct and improve them, so as to achieve the purpose of promoting teaching. Therefore, we should pay more attention to teachers' self-evaluation and expert evaluation, the combination of student evaluation and a certain system of reward and punishment to improve the quality of teaching and improve the sense of effectiveness of teachers.

\section{CONCLUSION}

The sense of teaching efficacy of college English teachers provides motivation and enthusiasm for their work. It is the source of teachers' pursuit of progress in teaching. 
The cultivation of teachers' sense of teaching efficacy can promote the deepening of contemporary new educational concepts, and ensure the implementation and implementation of English teaching reform in colleges and universities. This article discusses influencing factors and promotion strategies which will benefit the English educators in colleges and universities.

\section{REFERENCES}

[1] Bandura. Self-Efficacy: the Exercise of Control [M]. Miu Xiaochun et al. Shanghai: East China Normal University press, 1999. [美] 班杜 拉. 自我效能: 控制的实施 $[\mathrm{M}]$. 缪小春等译. 上海: 华东师范大学 出版社, 1999.

[2] Yu Guoliang, Xin Tao, Shen Ji Liang. Teachers' Sense of Teaching Efficacy: Research on Structure and Influencing Factors [J]. Journal of Psychology 1995 (5) 俞国良, 辛涛, 申继亮. 教师教学效能 感: 结构与影响因素的研究[J]. 心理学报, 1995 (5)

[3] Yu Guoliang, Luo Xiao Lu. Research on Teachers' Teaching Efficacy Related Factors [J]. Journal of Beijing Normal University (HUMANITIES AND SOCIAL SCIENCES), 2000 (1) 俞国良, 罗 晓路. 教师教学效能感极其相关因素研究 $[\mathrm{J}]$. 北京师范大学学报 （人文社会科学版），2000（1）

[4] Li Ying. Research on the Promotion Strategies of College Teachers' Sense of Teaching Efficacy [J]. Journal of Changchun Normal University (HUMANITIES AND SOCIAL SCIENCES), 2010 (7) 李 莹. 关于高校教师教学效能感提升策略的研究 [J]. 长春师范学院学 报（人文社会科学版），2010（7）

[5] Li Ying. Research on Teaching Efficacy of University Teachers [D]. Master's Thesis of Zhongshan University, 2009 李莹 高校教师教学 效能感研究[D]. 中山大学硕士学位论文, 2009

[6] Wang Shi Yang, College English Teachers' Sense of Efficacy and Environmental Factors [D]. Zhejiang Normal University Master Degree Thesis, 2009 王诗婼 高校英语教师效能感极其环境因素研 究[D]. 浙江师范大学硕士学位论文, 2009 